\title{
Ulcerative keratitis and keratomalacia in a dog caused by papain: a case report
}

\author{
Paula Diniz Galera, ${ }^{*}$ Robert J. Munger, ${ }^{* *}$ José Luiz Laus***
}

\begin{abstract}
Corneal ulceration with keratomalacia (corneal melting) is a serious disorder that can produce blindness. A one-year-old male miniature Pinscher cross dog was presented with corneal edema caused by accidental exposure of the eye to papain (from papaya tree). Ophthalmic exam revealed severe corneal edema and keratomalacia in the left eye. This report describes the successful clinical management of the case with preservation of the cornea and vision.
\end{abstract}

Keywords: melting, keratomalacia, cornea, ulcerative keratitis, papain.

\begin{abstract}
Resumo
Ulceração corneana com ceratomalácia (melting corneano) é uma séria afecção ocular que pode resultar em perda da visão. Um cão mestiço de miniatura Pinscher, macho, com um ano de idade, foi atendido apresentando edema de córnea decorrente de exposição acidental do olho à papaína, proveniente do leite de mamão papaia. O exame oftálmico revelou edema corneano grave e ceratomalácia no olho esquerdo. Este relato descreve o sucesso do tratamento adotado, com a preservação da córnea e da visão.
\end{abstract}

Palavras-chave: melting, ceratomalácia, córnea, ceratite ulcerativa, papaína.

\section{Introduction}

Corneal ulcers related to collagenase and proteases activity may present with progressive stromal dissolution or keratomalacia (corneal melting). Keratomalacia is a complicating component of the ulcers rather than a specific keratopathy (Whitley \& Gilger, 1999). Such progressive stromal ulceration is a disorder of unique seriousness that can cause blindness (Nasisse, 1985), the physiological mechanisms responsible for melting and repair have been described (Fini et al., 1998). The physiological process of stroma dissolution caused by the activity of proteolytic substances were described (Wolfer \& Gahn, 1994). Proteases and collagenases are normally produced during corneal healing to facilitate the removal of devitalized cells and debris from the cornea. Corneal epithelium cells, fibroblasts, polymorphonuclear leukocytes, some bacteria and possibly some fungi produce proteases and collagenases (Whitley \& Gilger, 1999), and recent studies have identified metalloproteinase matrixes as the most active enzymes (Wagoner, 1997; Fini et al., 1998). It has been suggested that those enzymes take part in all stages of a corneal ulceration from the beginning of the epithelial defect up to the resolution of the ulcer (Fini et al., 1998).

Papain is the dry, purified latex from the Carica papaya fruit and is called "vegetal pepsin" since it contains enzymes which are similar to pepsin. However, unlike pepsin, which acts only on acid cultures (Corbett, 1982), papain acts on acid, neutral, or alkaline cultures. Papain contains several enzymes including peptidase I, which can change proteins into dipeptides or polypeptides (Robbers et al., 1997). Chemical injuries cause damage to the corneal epithelium and to the anterior segment of the eye, which can lead to permanent reduction of visual acuity (Wagoner, 1997).

The initial management for corneal injuries caused by chemical substances consists of abundant irrigation to remove the substance (Donzis \& Mondino, 1987). Management of severe ulcerative keratitis with progressive melting demands vigorous topical therapy with control of infection and neutralization of the activity of collagenase and other proteases on the cornea (Whitley \& Gilger, 1999).

The efficacy of collagenase inhibitors in treating keratomalacia has been questioned (Wolfer \& Grahn, 1994). Clinically they seem to have their major beneficial effect during the first 48 to 72 hours of the ulcerative process (Whitley \& Gilger, 1999). Acetylcysteine, cystein, sodium citrate, tetracycline ascorbate, tetracycline, EDTA, penicillin, heparin and fresh autogenous serum have been advocated for their anti-collagenase activity (Wolfer \& Grahn, 1994; Whitley \& Gilger, 1999). Acetylcysteine and serum are the most commonly utilized collagenase inhibitors in the clinical management of melting corneal ulcers. Additional adjunctive therapies to antimicrobial therapy include the application of epidermal growth factor (Swank \& Hosgood, 1996), fibronectin, and tissue adhesives. Depending on the severity and progression of the corneal ulcer, surgical treatment

* DVM, MSc, Associate Professor -UPIS/ Brasília, DF; Ophthalmology Unit - Department of Medicine and Surgery- College of Agricultural and Veterinarian Sciences - São Paulo State University - Jaboticabal, SP -- Brazil

** DVM, Diplomate American College of Veterinary Ophthalmologists - Animal Ophthalmology Clinic - Dallas Texas - USA

*** DVM, MSc, PhD; Ophthalmology Unit - Department of Medicine and Surgery- College of Agricultural and Veterinarian Sciences - São Paulo State University - Jaboticabal, SP - Brazil 
may be required (Whitley \& Gilger, 1999). Surgical options include third eyelid flaps (Hansen \& Guandalini, 1999; Mandel, 2000), conjunctival flaps and grafts, and corneal grafts (Donzis \& Mondino, 1987; Hansen \& Guandalini, 1999; Whitley \& Gilger, 1999; Mandel, 2000; Soong et al., 2000).

\section{Case report}

A one-year-old male Pinscher cross dog was taken to the Veterinary Hospital - Cuiabá University (UNIC) - MT. His left eye had been exposed to papain about one_hour before it arrived at the hospital. The accident occurred when the owner took a papaya fruit and the dog was below from the tree. The owners reported they noticed a corneal opacity and the dog rubbing a few minutes after the accident. They had flushed the eye with physiological saline solution and cow's milk. The animal had up-to-date vaccination and parasitological exam, and there were no other clinical signs.

The ophthalmic examination revealed photophobia and blepharospasm, seromucoid discharge and moderate conjunctival hyperemia. The cornea was opaque centrally, the corneal tissue was friable (Fig. 1), and fluorescein ${ }^{1}$ was retained over an area approximately $2 \mathrm{~mm}$ in diameter. The contralateral eye was normal.

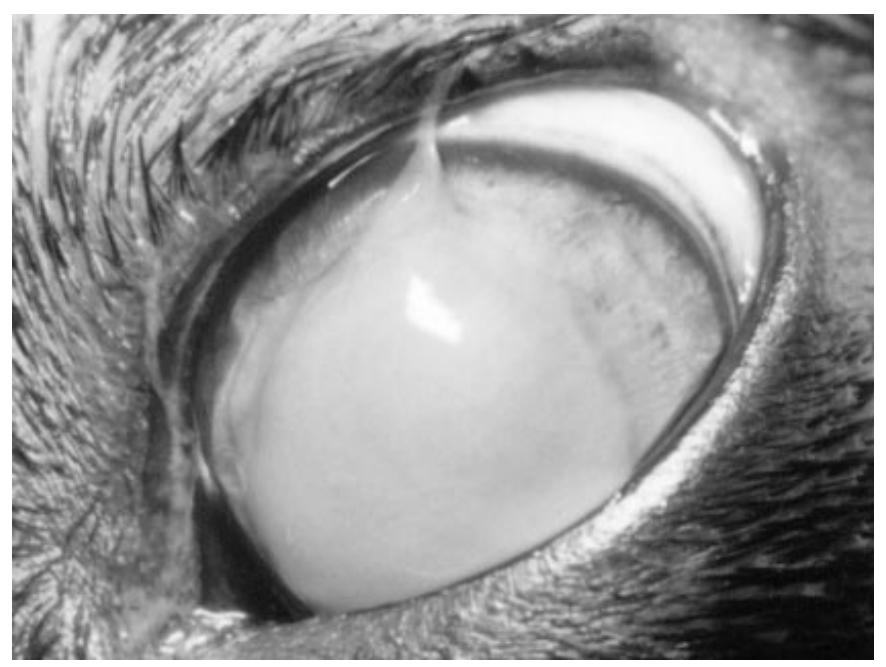

Figure 1: Photographic illustration in which corneal melting is evident in the left eye of a dog. This was the first exam made by the Ophthalmology Service.

In order to support the cornea during healing, a third eyelid flap was performed. Pre-anesthetic medication consisted of acepromazine $^{2}$ intravenously at a dose of $0.1 \mathrm{mg} / \mathrm{kg}$. Dissociative anesthesia was achieved through intramuscular administration of Tiletamin / Zolazepan ${ }^{3}$ at a dose of $0.2 \mathrm{ml} /$ $\mathrm{kg}$. Intravenous physiological solution of $0.9 \%$ saline was

\footnotetext{
Fluoresceína ${ }^{\circledR}$ - Allergan - Lok Prod. Farmacêuticos Ltda. Guarulhos - SP

2 Acepran 1\% ${ }^{\circledR}$ - Univet S.A. Ind. Veterinária - São Paulo - SP.

3 Zoletil 50 ® - Virbac do Brasil Indústria e Comércio Ltda. - São Paulo $-\mathrm{SP}$
}

administered during the surgery. The injured eye was abundantly flushed with sterile physiological saline solution for 20 minutes to remove residual papain. Next, topical anesthetic drops ${ }^{4}$ were applied to the eye and the necrotic corneal epithelium was debrided with a sterile cotton swab. Chloramphenicol ophthalmic solution ${ }^{5}$ was instilled at the rate of 2 drops every 5 minutes for 15 minutes plus 1 application of $1 \%$ atropine ophthalmic solution ${ }^{6}$. A third eyelid flap was performed using 6-0 monofilament nylon ${ }^{7}$ to suture the third eyelid to the upper eyelid. A subcutaneous injection of flunixin meglumine ${ }^{8}$ (1.1 $\mathrm{mg} / \mathrm{kg}$ ) was given to counter inflammation. Post-operative treatment of the eye included topical instillation of chloramphenicol $^{5}$ (one drop every 1 hour), $1 \%$ atropine ophthalmic solution $^{6}$ (one drop every 8 hours) and 10\% acetylcysteine ${ }^{9}$ (one drop every four hours) during the next 24 hours.

Twenty-four hours later the flap was released so that the lesion could be observed. The keratomalacia had decreased and the corneal ulcer was shallower. The third eyelid flap was replaced using the previously described anesthesic drugs and subcutaneous injection of flunixin meglumine ${ }^{8}$ was repeated. The therapeutic regimen was continued for 7 days with the addition of fresh autogenous serum (one drop every 4 hours) to aid in the neutralization of the keratomalacia (Renwick, 1996; Whitley e Gilger, 1999). The serum was prepared by centrifuging $3 \mathrm{ml}$ of blood collected from the patient. It was placed in a sterile dropper vial and was kept refrigerated at $4^{\circ} \mathrm{C}$. The serum was replaced with a freshly prepared sample every 3 days. An Elizabethan collar was used during all the post-operative surgery period to prevent self-trauma.

Eight days after the accident, the third eyelid flap was removed and the eye was re-examined. The cornea remained edematous with positive fluorescein ${ }^{10}$ retention in the center of the corneal lesion. The diameter of the corneal lesion was smaller than the initial. The instillations of fresh autogenous serum were discontinued, but topical antibiotic and atropine applications were continued. Sixteen days later, there had been good progression of corneal healing, there was no retention of fluorescein ${ }^{10}$ by the cornea, and a nebular corneal scar was present. Neomycin-polymyxin B- $0.1 \%$ dexamethasone ophthalmic solution ${ }^{11}$ (one drop every 8 hours) for 15 consecutive days) was started on the $21^{\text {st }}$ day after presentation to decrease the severity of corneal scarring. At the end of the treatment, a discrete macular scar was present, and the dog

\footnotetext{
4 Colírio anestésico® - Allergan - Lok Prod. Framacêuticos Ltda. Guarulhos - SP

5 Colírio de Cloranfenicol ${ }^{\circledR}$ - Allergan - Lok Prod. Framacêuticos Ltda. - Guarulhos - SP

6 Colírio de atropina 1\%® - Allergan - Lok Prod. Framacêuticos Ltda. Guarulhos - SP

7 Mononylon 6-0® - Ethicon S.A. - São José dos Campos - SP

8 Banamine Pet ${ }^{\circledR}$ - Ind. Químicas e Farmacêuticas Schering Plugh S.A. - Rio de Janeiro - RJ

9 Fluimucil 10\%® - Zambon Laboratório Farmacêutico Ltda. - São Paulo - SP

${ }^{10}$ Fluoresceína ${ }^{\circledR}$ - Allergan - Lok Prod. Farmacêuticos Ltda. - Guarulhos - SP

${ }^{11}$ Maxitrol ${ }^{\circledR}$ - Alcon Laboratório do Brasil Ltda. - São Paulo - SP
} 
exhibited good visual responses to "threat and labyrinth" tests. Thirteen months after the accident, a discreet scar was observed and the vision was normal (Fig. 2).

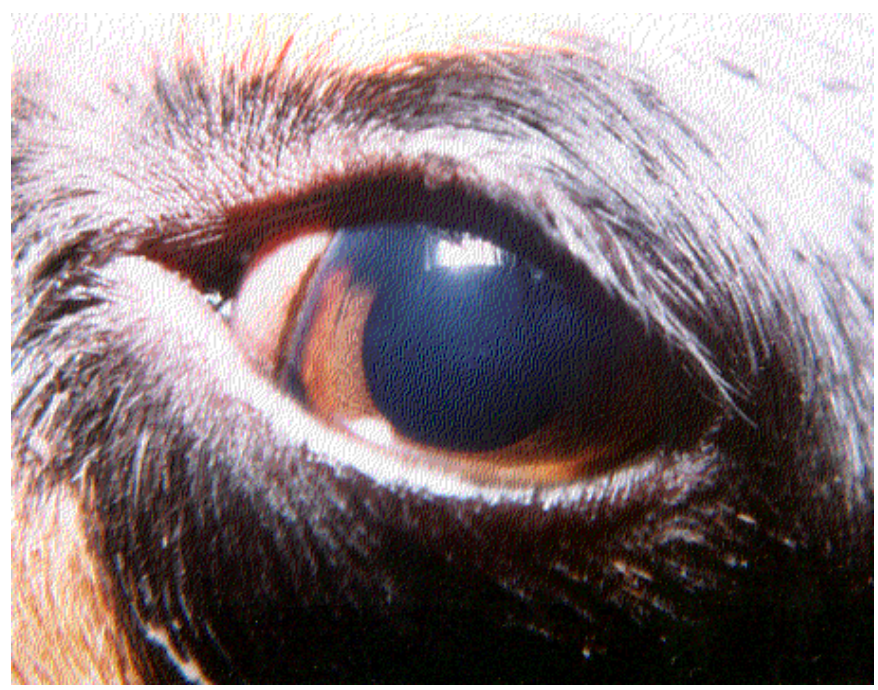

Figure 2: Photographic illustration of the dog left eye after 13 months after the treatment. A discreet scar was present. There was preservation of the cornea and vision.

\section{Discussion and conclusions}

Corneal ulcers complicated by excessive enzymatic activity become evident because of the corneal stroma dissolution, pain, and varying degrees of uveitis. Therapies such as the abundant irrigation of the eye and the use of topical antibiotics and atropine are extremely important to prevent infection, reduce pain and prevent synechia formation (Whitley \& Gilger, 1999). Little information is available in the veterinary literature regarding papain and the treatment for its deleterious effects on the eye. This case report describes the successful treatment of papain-induced ulcerative keratitis and keratomalacia in a dog.

\section{References}

CORBETT, C.E. Secreções e Motilidade do Tubo Digestivo. In: CORBETT, C.E. Farmacodinâmica. Cap. 8, 1982. p. 613.

DONZIS, P.B.; MONDINO, B.J. Management of Noninfectious Corneal Ulcers. Survey of Ophthalmology. v. 32, n. 2, p. 94-108, 1987.

FINI, M.E.; COOK, J.R.; MOHAN, R. Proteolytic Mechanisms in corneal ulceration and repair (Review). Archives of Dermatological Research. 290 Suppl. 1998; p.12-32.

HANSEN, P.A; GUANDALINI, A. A retrospective study of 30 cases of frozen lamellar corneal graft in dogs and cats. Veterinary Ophthalmology. v. 2, n. 4, p. 233-241, 1999.

MANDEL, D.C. Ophthalmic Emergencies (Review). Clinical Techniques in Small Animal Practice. v. 15, n. 2, p. 94-100, 2000.

NASISSE, M.P. Canine Ulcerative Keratitis. Comp. Continuing Education. v. 7, n. 9, p. 686-701, 1985.

RENWICK, P. Diagnosis and treatment of corneal disorders in dogs. In: Practice, v. 18, n. 7, p. 315-328, 1996.

ROBBERS, J.E.; SPEEDIE, M.K.; TYLER, V.E. Proteínas e Peptídeos. In: ROBBERS, J.E.; SPEEDIE, M.K.; TYLER, V.E. Farmacognosia e Farmacobiotecnologia. Cap. 10,1997. p. 214.
Many tissues, including the cornea, contain inhibitors of metalloproteinases and plasma proteases. Corneal destruction is caused by the imbalance between proteases and their inhibitors in favour of proteases. Even though the use of anticollagenolytic substances has been questioned (Wolfer \& Grahn, 1994; Whitley \& Gilger, 1999), it is believed that they are effective inhibitors of proteolytic enzymes in cases of acute corneal melting (Ward, 1999). Of the agents with proposed anticollagenolytic activity, acetylcysteine and fresh autogenous serum are the two most commonly utilized in veterinary ophthalmology. Acetylcysteine inhibits collagenase activity by binding active zinc $\left(\mathrm{Zn}^{++}\right)$receptor sites on the enzyme (Whitley \& Gilger, 1999).

Because ulcerative keratitis can cause reflex uveitis, systemic nonsteroidal anti-inflammatory medication is indicated for its anti-prostaglandin effects and good penetration into the ocular tissues (Tasaka, 1999).

Because corneal stromal loss and subsequent corneal perforation can occur rapidly, surgical procedures must often be employed adopted to block the progression of the corneal melting and support the damaged corneal tissue until healing can occur. Epithelial debridement removes the necrotic and non-adhered corneal epithelium, which allows the migration and multiplication of the adjacent corneal epithelium that is rich in hemidesmosomes and the production of new epithelial basal membrane (Whitley \& Gilger, 1999). Although the use of conjunctival flaps and grafts as well as corneal transplants are widely described in the literature (Donzis \& Mondino, 1987; Hansen \& Guandalini, 1999;Whitley \& Gilger, 1999; Mandel, 2000; Soong et al., 2000), a third eyelid flap as recommended because of its simplicity of the procedure and because it is less susceptible to the melting processes than conjunctival and corneal grafts (Mandel, 2000; Soong et al., 2000). The success of these measures is evident from the resolution of the keratomalacia and reflex uveitis, the preservation of vision, and the improved corneal clarity. The administration of immediate first aid by the owners of the dog and their adherence to treatment protocols were influential beneficial factors as well.

SWANK, A.; HOSGOOD, G. Corneal Wound Healing and the role of Growth Factors. Comp. on Continuing Education, v. 18, n. 9, p. 1007-1018, 1996. SOONG, H.K.; FARJO, A.A.; KATZ, D. et al. Lamellar corneal patch grafts in the management of corneal melting. Cornea, v. 19, n. 2, p. 126-134, 2000.

TASAKA, A.C. Antiinflamatórios não esteroidais. In: SPINOSA, H.S.; GORNIÁK, S.L. BERNARDI, M.M. Farmacologia Aplicada à Medicina Veterinária. 2. ed. Rio de Janeiro: Guanabara Koogan. 1999. p. 222.

WAGONER, M.D. Chemical injuries of the Eye: Current Concepts in Pathophysiology and Therapy. Survey of Ophthalmology, v. 41, n. 4, p. 275-303, 1997.

WARD, D. Mydriatics/Cycloplegics, Anesthetics, Tear Substitutes and Stimulators, Intraocular Irrigating Fluids, Disinfectants, Viscoelastics, Fibrinolytics and Antifibrinolytics, Antifibrotic Agents, Tissue Adhesives and Anticollagenase Agents-Part3. In: GELATT, K.N. Veterinary Ophthalmology, $3^{\text {rd }}$ Ed. Lippincott Willians \& Wilkins. Cap. 8, 1999, p. 336-354.

WHITLEY, R.D.; GILGER, B.C. Diseases of the Canine Cornea and Sclera. In: GELATT, K.N. Veterinary Ophthalmology, $3^{\text {rd }}$ Ed. Lippincott Willians \& Wilkins, Cap.19, 1999, p. 635-673.

WOLFER, J.; GRAHN, B. Ophthalmology Diagnostique. Canine Veterinary Journal. v. 35, p. 124-125, 1994. 